\title{
CEPF Burrowing Frog (Fejervarya cepfi) as Prey of a Terrestrial Beetle Larva (Epomis sp.)
}

Anish Pardeshi ${ }^{1}$, Samruddha Patil ${ }^{2}$, and Ankur Moitra ${ }^{3}$

${ }^{1} 1701$ Sadashiv Peth, Vishnu Apartment, Tilak Road, Pune, Maharashtra (anishpardeshi103@gmail.com)

${ }^{2}$ Sahakar Building Mahim, Mumbai 40016, Maharashtra (samruddaspatil@gmail.com)

3201, Tulsi CHS, Sector 09 Airoli, Maharashtra (ankurmoitra4@gmail.com)

A mphibians are important prey for numerous arthropod taxa, including ground beetles (e.g., Toledo 2005; Bernard and Samolag 2014). Previous studies have shown that the larvae of ground beetles in the genus Epomis feed exclusively on amphibians and display a unique luring behavior in order to attract their prey (Wizen et al. 2011). Moreover, the larval mandibles are characterized by two curved hooks, a modification for grasping amphibian skin (Brandmayr et al. 2010). However, published observations of Epomis beetles attacking amphibians are scarce, with reports from Japan (Crossland et al. 2016), the Middle East (Wizen and Gasith 2011), and two from India (Barve and Chaboo 2011; Wizen et al. 2017). Herein we report predation by Epomis larvae on a CEPF Burrowing Frog (Fejervarya cepfi), a recently described endemic species known from only a few localities in the northern Western Ghats of Maharashtra, India (Garg and Biju 2017).

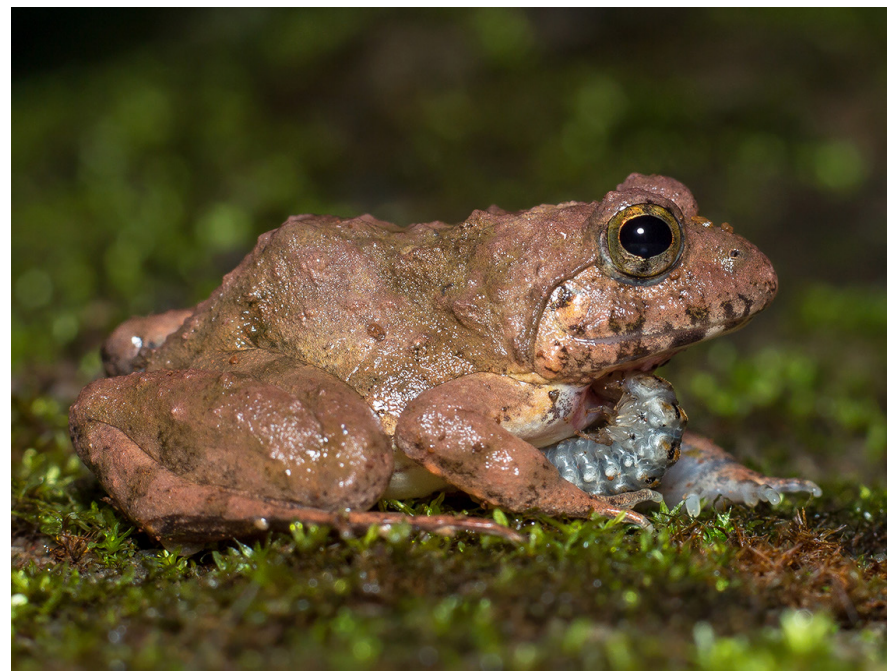

Fig. 1. Predation on a CEPF Burrowing Frog (Fejervarya cepfi) by a ground beetle larva (Epomis sp.) in Amboli Forest, Sindhudurg District, Maharashtra, India. Photograph by Samruddha Patil.
At $1600 \mathrm{~h}$ on 12 September 2017, during an amphibian survey at Amboli Forest, a hilly location in the northern Western Ghats in Sindhudurg District, Maharashtra, India $\left(15.964681^{\circ} \mathrm{N}, 74.003616^{\circ} \mathrm{E}\right.$; WGS 84; elev. $690 \mathrm{~m}$ asl), we observed a CEPF Burrowing Frog on the ground near a pond in the forest. Upon closer inspection, we noticed that the frog (SVL ca. $30 \mathrm{~mm}$ ) had a small beetle larva attached to its throat (Fig. 1). The larva was a first-instar (the first of five larval stages) Epomis larva. The frog appeared otherwise healthy, was not struggling, seemed to behave normally, and moved about on the ground without problems. We collected neither the frog nor the larva.

The frog probably encountered the Epomis larva on the ground, and the location of the larva on the frog's throat suggests that the larva enticed the frog to approach by displaying its characteristic luring behavior (Wizen et al. 2011). Because Epomis larvae feed exclusively on amphibians in an ectoparasitic manner, the interaction is usually fatal to the amphibian.

Our observation suggests that a population of Epomis beetles exists in the area and that its dependence on frogs as prey could have a negative effect on anuran populations. We propose additional monitoring of both frog and beetle populations to evaluate the impact of the beetles on the anuran populations in this region.

\section{Acknowledgements}

We thank Varad Giri and K.V. Gururaja for help with identification of the species, and Kaka Bhise for valuable support.

\section{Literature Cited}

Barve, V.V. and C.S. Chaboo. 2011. Duttaphrynus scaber (Ferguson's Toad). Predation by beetles. Herpetological Review 42: 83-84.

Bernard, S. and J. Samolag. 2014. An event of underground predation on a wintering caudate amphibian by a carabid beetle. Entomologica Fennica 25: 157-160.

Brandmayr, P., T. Bonacci, and T.Z. Brandmayr. 2010. Larval morphology of Epomis circumscriptus (Duftschmid 1812) and of first instar E. dejeani, Dejean, 1831, (Coleoptera, Carabidae, Chlaeniini) with morphofunctional remarks. Zootaxa 2388: 49-58. 
Crossland, M., T. Haramura, and R. Shine. 2016. Fejervarya sakishimensis (Sakishima Rice Frog). Predation by terrestrial beetle larva. Herpetological Review 47: 107-108.

Garg, S. and S.D. Biju. 2017. Description of four new species of burrowing frogs in the Fejervarya rusescen complex (Dicroglossidae) with notes on morphological affinities of Fejervarya species in the Western Ghats. Zootaxa 4277: 451-490.

Toledo, L.F. 2005. Predation of juvenile and adult anurans by invertebrates:
Current knowledge and perspectives. Herpetological Review 36: 395-399.

Wizen, G. and A. Gasith. 2011. An unprecedented role reversal: ground beetle larvae (Coleoptera: Carabidae) lure amphibians and prey upon them. PloS ONE 6: e25161.

Wizen, G., A. Pardeshi, and K. Bhise. 2017. Pseudophilautus amboli (Amboli Bush Frog). Predation by terrestrial beetle larvae. Herpetological Review 48: 612. 